\title{
Regional test of a model for shallow landsliding
}

\author{
David R. Montgomery, ${ }^{1 *}$ Kathleen Sullivan ${ }^{2}$ and Harvey M. Greenberg ${ }^{1}$ \\ ${ }^{1}$ Department of Geological Sciences, University of Washington, Seattle, WA, USA \\ ${ }^{2}$ Environmental Research, Weyerhaeuser Co., Tacoma, WA, USA
}

\begin{abstract}
:
Landslides mapped in 14 watershed analyses in Oregon and Washington provide a regional test of a model for shallow landsliding. A total of 3224 landslides were mapped in watersheds covering $2993 \mathrm{~km}^{2}$ and underlain by a variety of lithologies, including Tertiary sedimentary rocks of the Coast Ranges, volcanic rocks of the Cascade Range and Quaternary glacial sediments in the Puget Lowlands. GIS (geographical information system) techniques were used to register each mapped landslide to critical rainfall values predicted from a theoretical model for the topographic control on shallow landsliding using $30 \mathrm{~m}$ DEMs (digital elevation models). A single set of parameter values appropriate for simulating slide hazards after forest clearing was used for all watersheds to assess the regional influence of topographic controls on shallow landsliding. Model performance varied widely between watersheds, with the best performance generally in steep watersheds underlain by shallow bedrock and the worst performance in generally low gradient watersheds underlain by thick glacial deposits. Landslide frequency (slides $/ \mathrm{km}^{2}$ ) varied between physiographic provinces but yielded consistent patterns of higher slide frequency in areas with lower critical rainfall values. Simulations with variable effective cohesion predicted that high root strength effectively limits shallow landsliding to topographic hollows with deep soils and locations that experience excess pore pressures, but that low root strength leads to higher probabilities of failure across a greater proportion of the landscape. (C) 1998 John Wiley \& Sons, Ltd.
\end{abstract}

KEY WORDS landslides; GIS; model testing, forest management

\section{INTRODUCTION}

Shallow landsliding can dominate sediment transport in steep, soil-mantled landscapes (Swanson et al., 1982; Dietrich et al., 1986; Benda, 1990; Seidl and Dietrich, 1992) and topographically-driven convergence of both soil and runoff favour the initiation of shallow landslides in fine-scale topographic hollows (Williams and Guy, 1971; Dietrich et al., 1986). The downstream disturbance, scour and deposition from shallow landslides that transform into debris flows can adversely affect channels, people, fish and property. Land use can affect shallow landsliding and, even though many studies have demonstrated acceleration of landsliding following road construction and timber harvest (e.g. Fredriksen, 1970; Brown and Krygier, 1971; Mersereau and Dyrness, 1972; Swanson and Dyrness, 1975; Swanston and Swanson, 1976; Gresswell et al., 1979), doubts are still voiced over the role of forest clearing on the initiation of shallow landslides (e.g. Skaugest et al., 1993; Martin et al., 1996). Historically, lack of methods to stratify equivalent topographic influences on shallow landsliding compromised evaluation of the effects of land management. GIS-driven models can provide a spatially distributed prediction of the relative role of topographic influences on shallow landslide

\footnotetext{
* Correspondence to: David R. Montgomery, Department of Geological Sciences, University of Washington, Seattle, WA 98195, USA.

Contract grant sponsors: Weyerhaeuser Company; Cooperative State Research Services; USDA; USFS; NFS.

Contract grant numbers: 94-37101-0321 (USDA); PNW 93-0441 (USFS); CMS-9610269 (NSF). 
initiation (e.g. Dietrich et al., 1993; Montgomery and Dietrich, 1994; Wu and Sidle, 1995), and an extensive programme of landslide mapping conducted during recent watershed analyses (WFPB, 1993) provides an opportunity for regional tests of such models. Here we use data from 14 watersheds in Oregon and Washington to examine the performance of a model for the topographic control of shallow landsliding.

\section{MODEL}

Landslide hazard assessments are based on a variety of approaches and assumptions. Many approaches rely on either multivariate correlations between mapped landslides and landscape attributes (e.g. Neuland, 1976, 1980; Carrara et al., 1977, 1991; Carrara, 1983; Mark, 1992; Busoni et al., 1995), or general associations of landslide hazard from rankings based on slope, lithology, land form or geological structure (e.g. Brabb et al., 1972; Campbell, 1975; Hollingsworth and Kovacs, 1981; Lanyon and Hall, 1983; Seely and West, 1990; Montgomery et al., 1991; Niemann and Howes, 1991; Derbyshire et al., 1995). The approach explored here builds on the physics-based modelling pioneered by Okimura and colleagues (Okimura and Ichikawa, 1985; Okimura and Nakagawa, 1988) and extended by others (e.g. Dietrich et al., 1993, 1995; van Asch et al., 1993; Montgomery and Dietrich, 1994) to develop a simple model of pre- and post-cutting hazard from shallow landsliding.

Our approach is based on coupling a hydrological model to a limit-equilibrium slope stability model to calculate the critical steady-state rainfall necessary to trigger slope instability at any point in a landscape. The hydrological model maps the spatial pattern of equilibrium soil saturation based on analysis of upslope contributing areas, soil transmissivity and local slope (O'Loughlin, 1986). Flow is assumed to infiltrate to a lower conductivity layer and follow topographically determined flow paths. Local wetness $(W)$ is calculated as the ratio of the local flux at a given steady-state rainfall $(Q)$ to that upon complete saturation of the soil profile

$$
W=\frac{Q a}{b T \sin \theta}
$$

where $a$ is the upslope contributing area $\left(\mathrm{m}^{2}\right), b$ is the length across which flow is accounted for (m), $T$ is the depth-integrated soil transmissivity $\left(\mathrm{m}^{2} /\right.$ day) and $\theta$ is the local slope (degrees). Adopting the simplifying assumption that the saturated conductivity does not vary with depth, Equation (1) can be reduced for the case where $W \leqslant 1$ to

$$
W=h / z
$$

where $h$ is the thickness of the saturated soil above the impermeable layer and $z$ is the total thickness of the soil. Combining Equations (1) and (2) allows expression of the relative saturation of the soil profile as

$$
h / z=\frac{Q a}{b T \sin \theta}
$$

which predicts relative soil moisture as a function of steady-state rainfall, specific catchment area $(a / b)$, soil transmissivity and local slope.

The infinite-slope stability model provides a one-dimensional model for failure of shallow soils that neglects arching and lateral root reinforcement. Under these assumptions the criterion for slope failure may be expressed as

$$
\rho_{\mathrm{s}} g z \sin \theta \cos \theta=C^{\prime}+\left[\rho_{\mathrm{s}}-(h / z) \rho_{w}\right] g z \cos ^{2} \theta \tan \phi
$$

where $\rho_{\mathrm{s}}$ is the bulk density of the soil, $g$ is gravitational acceleration, $z$ is soil thickness, $C^{\prime}$ is the effective cohesion of the soil including the effect of reinforcement by roots that penetrate the basal failure surface, $\rho_{\mathrm{w}}$ 
is the bulk density of water and $\phi$ is the friction angle of the soil (e.g. Selby, 1982). Combining Equations (3) and (4) and rearranging in terms of the critical steady-state rainfall $\left(Q_{\mathrm{c}}\right)$ necessary to trigger slope instability, yields

$$
Q_{\mathrm{c}}=\frac{T \sin \theta}{(a / b)}\left[\frac{C^{\prime}}{\rho_{\mathrm{w}} g z \cos ^{2} \theta \tan \phi}+\frac{\rho_{\mathrm{s}}}{\rho_{\mathrm{w}}}\left(1-\frac{\tan \theta}{\tan \phi}\right)\right]
$$

For the case of cohesionless soils (i.e. $C^{\prime}=0$ ) this reduces to the model explored in greater detail by Montgomery and Dietrich (1994)

$$
Q_{\mathrm{c}}=\frac{T \sin \theta}{(a / b)}\left[\frac{\rho_{\mathrm{s}}}{\rho_{\mathrm{w}}}\left(1-\frac{\tan \theta}{\tan \phi}\right)\right]
$$

The physical interpretation of $W$ greater than 1.0 is that for the excess water runs off as overland flow; hence, there is no mechanism in this model for generating pore pressures in excess of hydrostatic pressures. Slopes that are stable even when $W=1.0$ are interpreted to be unconditionally stable and to require excess pore pressures to generate slope instability. The condition for unconditionally stable slopes can be expressed as

$$
\tan \theta<\frac{C^{\prime}}{\rho_{\mathrm{s}} g z \cos ^{2} \theta}+\left(1-\frac{\rho_{\mathrm{w}}}{\rho_{\mathrm{s}}}\right) \tan \phi
$$

Similarly, slopes predicted to be unstable even when dry (i.e. $W=0$ ) are considered to be unconditionally unstable areas where soil accumulation would be difficult and therefore one would expect to find rock outcropping. The condition for unconditionally unstable slopes can be expressed as

$$
\tan \theta \geqslant \tan \phi+\frac{C^{\prime}}{\rho_{\mathrm{s}} g z \cos ^{2} \theta}
$$

Critical rainfall values can be calculated for locations with slopes between the criteria of Equations (6) and (7).

The model given by Equations (5)-(7) can be implemented using either topographic elements defined by contours and flow lines, or by the square grid cells typical of digital elevation models (DEMs). Comparison of the location of field-mapped landslides and $Q_{\mathrm{c}}$ values predicted under the assumption of cohesionless soils supports the interpretation that locations with equal $Q_{\mathrm{c}}$ have equal topographic control on shallow landslide initiation in three small drainage basins in the western United States (Montgomery and Dietrich, 1994). The steady-state rainfall and cohesionless soil assumptions, however, complicate translation of $Q_{\mathrm{c}}$ values into actual failure probabilities. Lateral reinforcement by roots that extend across the side of potential failures (Burroughs, 1984; Reneau and Dietrich, 1987) and systematic variations in soil thickness also influence the probability of slope failure (Dietrich et al., 1995). Without calibration to field data our approach can only identify areas with equal topographic control on shallow landslide initiation.

Spatial variations in soil properties also influence the probability of failure and the location of specific failures may be strongly influenced by site-specific details such as interaction of flow in colluvial soil and near-surface fractured bedrock (e.g. Montgomery et al., 1997). Variation in the amount of hydrological leakage to deeper groundwater flow may also strongly influence patterns of landsliding. Consequently, it is likely that within areas of equal topographic control on shallow landslide initiation some locations will be more or less susceptible to failure. Moreover, soil thickness increases through time in topographic hollows (e.g. Dietrich and Dunne, 1978; Dietrich et al., 1995) and these changes will lead to an increasing probability of slope failure as a hollow infills with colluvium (Dunne, 1991; Montgomery, 1991). At a specific location, however, the other soil and topographic properties incorporated in Equation (5) do not change through time 
and failures are initiated through changes in the thickness of the saturated zone in response to high intensity or long duration storms (Caine, 1980).

The magnitude of soil reinforcement by root strength varies both between species and in response to timber felling (Takahasi, 1968; Endo and Tsuruta, 1969; Burroughs and Thomas, 1977; Ziemer and Swanston, 1977; Wu et al., 1979; Riestenberg and Sovonick-Dunford, 1983; Reneau and Dietrich, 1987). Much of the total tensile strength of root systems resides in the finest roots, which die back rapidly following forest clearing (Burroughs and Thomas, 1977; Ziemer and Swanston, 1977). Total root strength decreases to a minimum between 3 and 15 years after timber harvest and returns to values similar to mature forest only after several decades (e.g. Sidle, 1992). Burroughs and Thomas (1977) estimated total tensile strength per unit area of soil imparted by mature Coast Douglas fir (Psuedotsuga menziesii) to be about $17 \mathrm{kN} / \mathrm{m}^{2}$, declining rapidly after cutting to about $2 \mathrm{kN} / \mathrm{m}^{2}$ for stumps. Less cohesion is attributable to root systems of other species; hardwood species range from 2 to $13 \mathrm{kN} / \mathrm{m}^{2}$ (Takahasi, 1968; Endo and Tsuruta, 1969; Riestenberg and SovonickDunford, 1983; Reneau and Dietrich, 1987); woody shrubs and ground cover are typically $<3 \mathrm{kN} / \mathrm{m}^{2}$ (Burroughs, 1984; Terwilliger and Waldron, 1991). The effective cohesion imparted to a soil by tree roots varies spatially, with depth and spacing of trees and with tree age. Although the full tensile strength of roots is not always mobilized during slope failure, examination of debris flow scarps in California, Oregon and Washington revealed that most exposed roots were sheared in the lateral margins and headscarps of shallow landslides. Comparison of the net root strength required for slope stability under the infinite-slope model and a lateral root strength model (Reneau and Dietrich, 1987) reveals that significantly greater root strength is required for the finite (i.e. lateral) than the infinite-slope model. Hence, calculations based on the infiniteslope model should yield a minimum constraint on the contribution of root strength to soils in which roots do not extend through the basal failure surface.

\section{STUDY AREAS AND METHODS}

We analysed data from 14 watersheds assessed under the Washington State watershed analysis methodology (WFPB, 1993). The study watersheds range in size from $119 \mathrm{~km}^{2}$ to $323 \mathrm{~km}^{2}$ and occupy a total of $2993 \mathrm{~km}^{2}$ spread across several physiographic provinces (Figure 1) and encompassing a wide range of geology and landforms (Table I). Each of the watersheds has been completely logged over the past 100 years, and some areas are in their third rotation of industrial forestry.

We chose to model relative slope stability using a single set of soil properties in order to focus on the topographic control on shallow landsliding. Based on extensive field measurement at a study site in coastal Oregon (Montgomery et al., 1997) we used values of $T=65 \mathrm{~m}^{2} /$ day, $\rho_{\mathrm{s}}=2000 \mathrm{~kg} / \mathrm{m}^{3}, z=1.0 \mathrm{~m}$ and $\phi=33^{\circ}$ for our analyses of each watershed, although we recognize that local variations in geology and soils should strongly influence patterns of landsliding. We therefore expect the model to perform poorly in areas with high recharge to deep groundwater, and other areas where the model assumptions are not well met. We presume that models which incorporate spatially distributed, watershed-specific soil and geological factors should perform better than the general model we investigate here. The use of a single set of parameter values, however, allows a unique regional test of the influence of topographic forcing on shallow landsliding, and also allows for comparison of the effect of lithology by controlling for topographic influences.

Landslides visible on aerial photographs were mapped on to $1: 24000$ scale topographic maps in each watershed. Aerial photograph coverage extended from the 1940s to the 1990s in most of the watersheds. Landslides were classified into shallow and deep-seated varieties, and the former were subdivided into 'in unit' failures and those interpreted to reflect road-related influences (e.g. drainage concentration, fill berm

failures, etc.). Landslide mapping did not always delineate slide scarps separately; slide outlines therefore may include initiation, transport and depositional areas. Also, comparison of aerial photographs and composite slide maps indicates that many small slides were not mapped in the watershed analyses apparently due to time, budget and resolution constraints. Hence, the extent of landsliding revealed by the watershed analyses provides a minimum estimate of contemporary rates of shallow landsliding. 


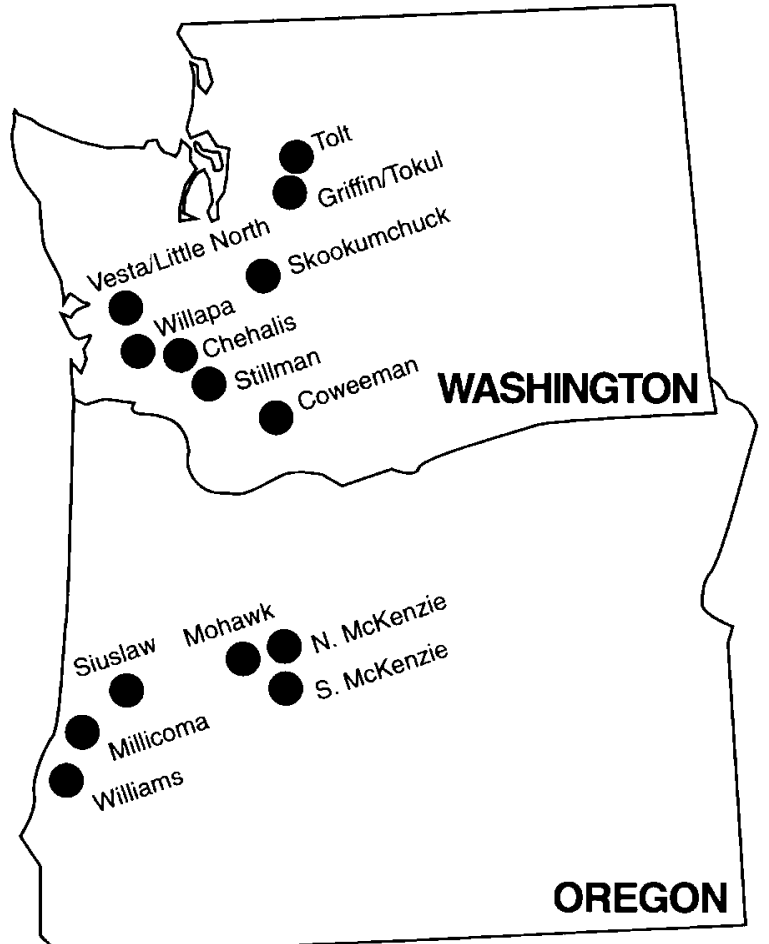

Figure 1. Location of the study watersheds

Table I. Characteristics of watersheds included in the study area

\begin{tabular}{|c|c|c|c|c|}
\hline State & Watershed & Physiographical area & Dominant lithology & Area $\left(\mathrm{km}^{2}\right)$ \\
\hline \multirow{8}{*}{ Washington } & Griffin/Tokul & Puget Sound Lowlands & Glacial outwash & $159 \cdot 1$ \\
\hline & Tolt & $\begin{array}{l}\text { Puget Sound Lowlands/ } \\
\text { Central Cascades }\end{array}$ & Glacial outwash/andesites & $244 \cdot 5$ \\
\hline & Skookumchuck & Central Cascades & Basalt/andesite & 158.9 \\
\hline & Coweeman & Central Cascades & Basalt/andesite & $182 \cdot 3$ \\
\hline & Stillman & Coast Range & $\begin{array}{l}\text { Tertiary sedimentary/extrusive } \\
\text { and intrusive basalt }\end{array}$ & $118 \cdot 5$ \\
\hline & Chehalis & Coast Range & $\begin{array}{l}\text { Tertiary sedimentary/extrusive } \\
\text { and intrusive basalt }\end{array}$ & $181 \cdot 7$ \\
\hline & Vesta/Little North & Coast Range & Sandstone/siltstone & $227 \cdot 3$ \\
\hline & Willapa & Coast Range & $\begin{array}{l}\text { Sedimentary/extrusive and } \\
\text { intrusive basalt }\end{array}$ & $254 \cdot 7$ \\
\hline \multirow[t]{6}{*}{ Oregon } & Siuslaw & Coast Range & $\begin{array}{l}\text { Sedimentary sandstone and } \\
\text { siltstone }\end{array}$ & $270 \cdot 6$ \\
\hline & Millicoma & Coast Range & $\begin{array}{l}\text { Sedimentary sandstone and } \\
\text { siltstone }\end{array}$ & $230 \cdot 9$ \\
\hline & Williams & Coast Range & $\begin{array}{l}\text { Sedimentary sandstone and } \\
\text { siltstone }\end{array}$ & $322 \cdot 9$ \\
\hline & Mohawk & Cascades foothills & Pyroclastic & $211 \cdot 2$ \\
\hline & $\begin{array}{l}\text { Lower McKenzie } \\
\text { (north) }\end{array}$ & Cascades & Tertiary volcanics & $244 \cdot 2$ \\
\hline & $\begin{array}{l}\text { Lower McKenzie } \\
\text { (south) }\end{array}$ & Cascades & Tertiary volcanics & $206 \cdot 6$ \\
\hline Total & & & & $2993 \cdot 4$ \\
\hline
\end{tabular}


The outline of each landslide was digitized to create a landslide polygon coverage for GIS analysis. The digitized landslide layer was rectified to composite $30 \mathrm{~m}$ grid USGS digital elevation models of each catchment. Critical rainfall values were calculated using the parameter values discussed above. Each landslide was attributed to the lowest $Q_{\mathrm{c}}$ category that it overlapped in order to account for both mapping and registration errors and the inclusion of transport and depositional areas in the slide polygons. Although simulations were run for three different cohesion values for each watershed $\left(2,8\right.$ and $\left.15 \mathrm{kN} / \mathrm{m}^{2}\right)$, here we focus on the analyses for $C^{\prime}=2 \mathrm{kN} / \mathrm{m}^{2}$, which approximates the post-cutting root strength minima in this region (Figure 2). Comparison of the relative frequency of slides within each $Q_{\mathrm{c}}$ category provides for direct testing of the assumption that lower $Q_{\mathrm{c}}$ implies higher failure frequency.

\section{RESULTS}

The distribution of the 3224 mapped landslides indicates that rates of shallow landsliding varied dramatically between the watersheds (Table II). The Skookumchuck watershed had the lowest number of observed slides (39) and the Chehalis watershed had the highest (629). Grouping of landslide frequency data by physiographic provinces yields subregional trends (Figure 3). Watersheds in coastal Washington underlain by sedimentary and igneous rocks have the highest rates of sliding; rates are substantially lower in the other areas.

In spite of such differences in slide frequency, the size distribution of shallow landslides mapped in these watersheds follows a roughly exponential distribution (Figure 4). Very few slides involve more than $20000 \mathrm{~m}^{2}$ and most involve less than $10000 \mathrm{~m}^{2}$; the mean slide size was $8152 \mathrm{~m}^{2}$ and the median size was $3386 \mathrm{~m}^{2}$. Because of their great number, small slides contribute substantially to the net sediment flux. The sizes of the mapped landslide polygons, however, reflect both mapping scale and the fact that the size of the total area influenced by the slide can be much larger than the initiation zone. The initial area of typical shallow landslides in this region is less than several thousand square metres (Pierson, 1977; Reneau and Dietrich, 1987), and the exponential distribution of total slide sizes quantifies the addition of material scoured from downstream areas in the runout path. Although it appears that a simple exponential function may account for variations in the downslope growth of slides, the disproportionately large number of slides

Table II. Landslide frequency (slides $/ \mathrm{km}^{2}$ ) in each critical rainfall category $(\mathrm{mm} /$ day) for the 14 study watersheds based on $C^{\prime}=2 \mathrm{kN} / \mathrm{m}^{2}$ and other parameters cited in the text

\begin{tabular}{|c|c|c|c|c|c|c|c|c|}
\hline Watershed & $\begin{array}{l}\text { Uncond. } \\
\text { unstable }\end{array}$ & $0-50$ & $50-100$ & $100-200$ & $200-400$ & $400+$ & $\begin{array}{l}\text { Uncond. } \\
\text { stable }\end{array}$ & $\begin{array}{c}\text { Watershed } \\
\text { Total }\end{array}$ \\
\hline Chehalis & $30 \cdot 5$ & $19 \cdot 4$ & $8 \cdot 5$ & $4 \cdot 5$ & $2 \cdot 7$ & $0 \cdot 9$ & $0 \cdot 5$ & $3 \cdot 5$ \\
\hline Coweeman & $6 \cdot 5$ & $10 \cdot 6$ & $3 \cdot 1$ & $0 \cdot 8$ & $0 \cdot 5$ & 0 & $0 \cdot 2$ & $0 \cdot 5$ \\
\hline Griffin/Tokul & 0 & $7 \cdot 6$ & $3 \cdot 6$ & $1 \cdot 1$ & 1.4 & $1 \cdot 9$ & 0.5 & 0.5 \\
\hline Millicoma & 8.9 & $3 \cdot 7$ & $2 \cdot 3$ & $1 \cdot 8$ & $1 \cdot 6$ & $2 \cdot 5$ & $0 \cdot 3$ & $1 \cdot 2$ \\
\hline Mohawk & $3 \cdot 7$ & $0 \cdot 8$ & $0 \cdot 8$ & $0 \cdot 4$ & $0 \cdot 3$ & 0 & $<0.1$ & $0 \cdot 2$ \\
\hline N. McKenzie & $19 \cdot 0$ & $4 \cdot 0$ & $1 \cdot 0$ & $0 \cdot 3$ & 0 & $1 \cdot 8$ & $0 \cdot 1$ & $1 \cdot 4$ \\
\hline S. McKenzie & $12 \cdot 8$ & $2 \cdot 3$ & $1 \cdot 1$ & $0 \cdot 6$ & 0.4 & 0 & $0 \cdot 1$ & $0 \cdot 9$ \\
\hline Siuslaw & $7 \cdot 3$ & $2 \cdot 8$ & $1 \cdot 5$ & $1 \cdot 2$ & $0 \cdot 9$ & $4 \cdot 0$ & $0 \cdot 1$ & $0 \cdot 4$ \\
\hline Skookumchuck & $4 \cdot 9$ & $2 \cdot 6$ & 0.5 & $0 \cdot 5$ & $0 \cdot 3$ & 0 & $<0.1$ & $0 \cdot 2$ \\
\hline Stillman & 0 & $16 \cdot 2$ & $9 \cdot 9$ & $7 \cdot 4$ & $2 \cdot 6$ & $3 \cdot 0$ & 0.7 & $1 \cdot 4$ \\
\hline Tolt & $1 \cdot 3$ & $2 \cdot 2$ & $1 \cdot 2$ & $1 \cdot 0$ & $1 \cdot 1$ & 0 & $0 \cdot 4$ & $0 \cdot 7$ \\
\hline Vesta & 0 & $30 \cdot 6$ & $30 \cdot 8$ & $19 \cdot 0$ & $10 \cdot 2$ & $4 \cdot 4$ & 0.7 & $1 \cdot 3$ \\
\hline Willapa & $35 \cdot 9$ & $20 \cdot 3$ & $8 \cdot 9$ & $3 \cdot 9$ & $2 \cdot 0$ & $1 \cdot 0$ & $0 \cdot 5$ & $1 \cdot 3$ \\
\hline Williams & $6 \cdot 7$ & $3 \cdot 0$ & $3 \cdot 1$ & $2 \cdot 5$ & $2 \cdot 1$ & $0 \cdot 9$ & $0 \cdot 3$ & $1 \cdot 4$ \\
\hline Totals & $9 \cdot 7$ & $4 \cdot 5$ & $2 \cdot 9$ & $2 \cdot 5$ & $2 \cdot 2$ & $1 \cdot 2$ & $0 \cdot 3$ & $1 \cdot 1$ \\
\hline
\end{tabular}




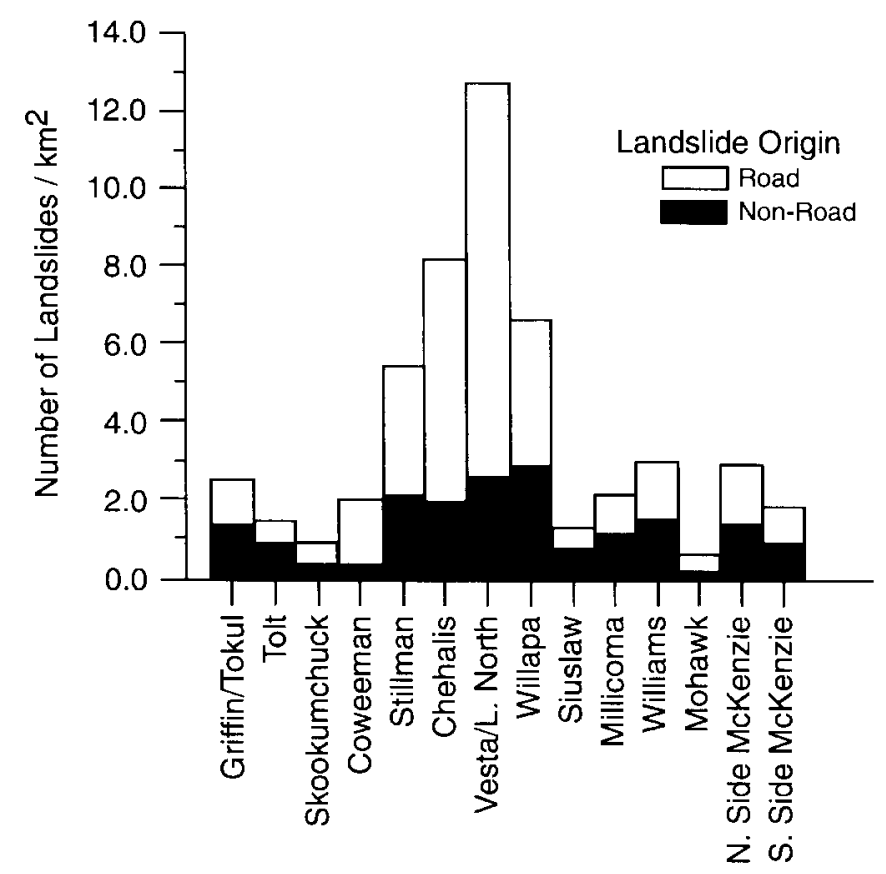

Figure 3. Aggregate landslide frequency for each watershed. Note that the coastal Washington watersheds have the highest rates of sliding

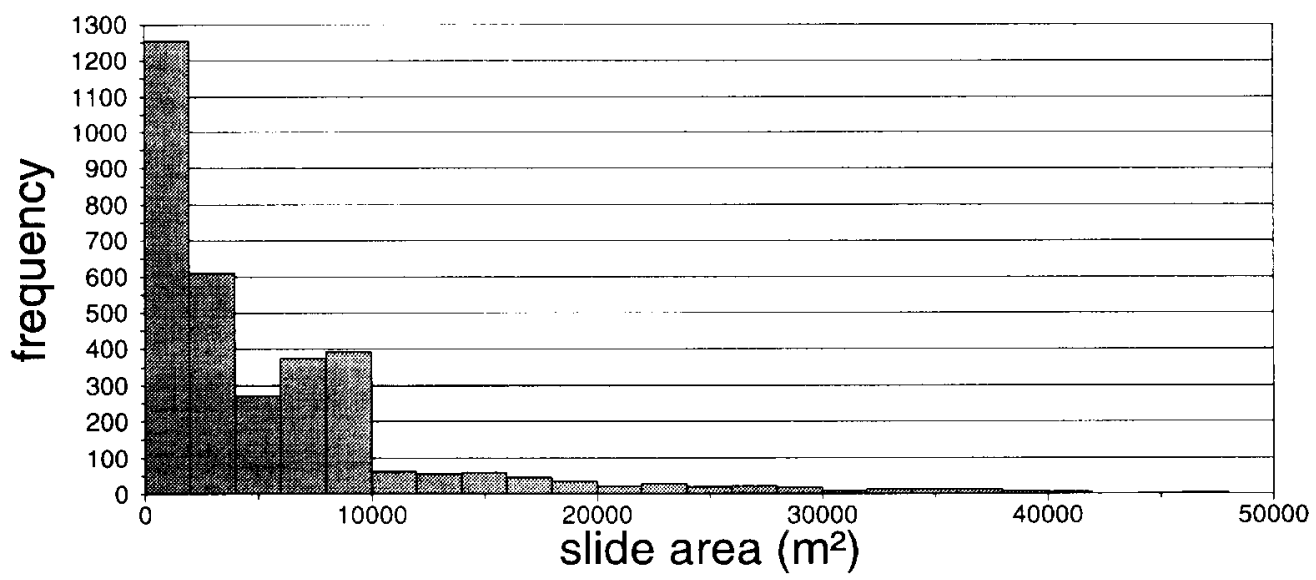

Figure 4. Size distribution of the 3224 mapped shallow landslides

about $10000 \mathrm{~m}^{2}$ in size may record enhanced growth of slides favourably oriented for propagation through the channel network (e.g. Grant et al., 1984; Benda and Dunne, 1987; Benda, 1990; Benda and Cundy, 1990).

The number of slides associated with each $Q_{\mathrm{c}}$ category varied widely between the watersheds. In some of the basins the majority of the slides occurred in the lowest $Q_{\mathrm{c}}$ categories (e.g. N. McKenzie), whereas in one basin (i.e. Griffin/Tokul) most slides occurred in areas predicted to be stable. The proportion of slides that occurred within $Q_{\text {c }}$ categories $<100 \mathrm{~mm} /$ day ranged from 7 to $92 \%$ across the study watersheds, and the proportion of slides that occurred within $Q_{\mathrm{c}}$ categories $<200 \mathrm{~mm} /$ day ranged from 9 to $93 \%$. The frequency of slides per unit area, however, consistently showed greater rates of sliding in areas predicted to have lower $Q_{\mathrm{c}}$ both within each watershed (Table II) and across all of the watersheds (Figure 5). 


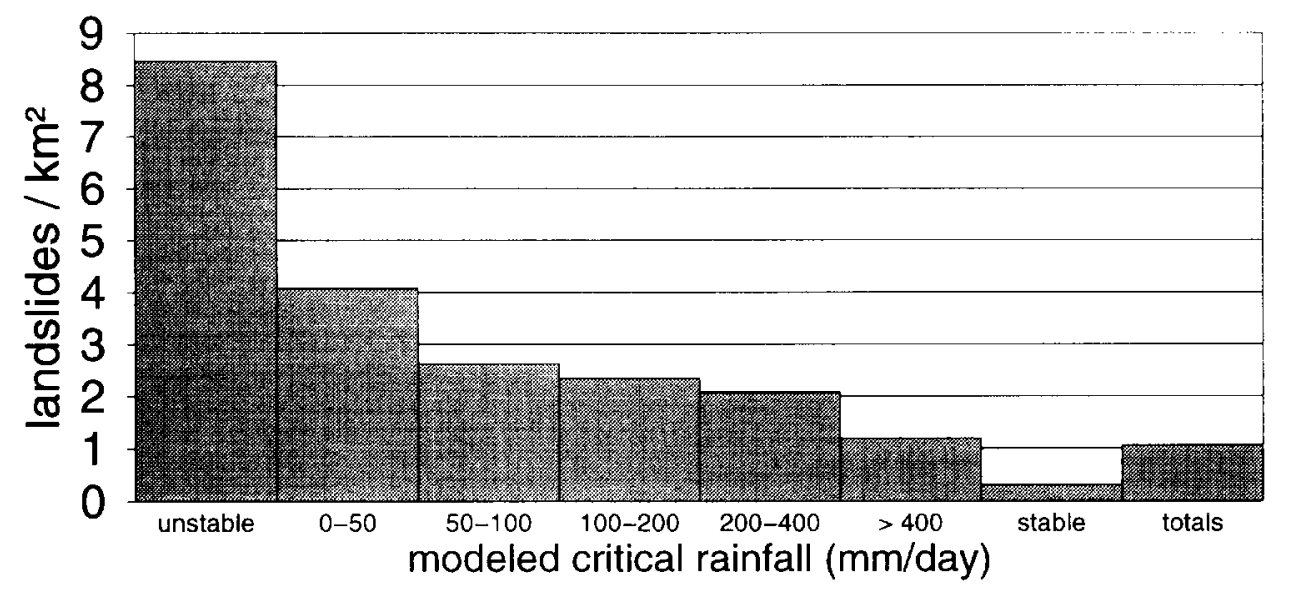

Figure 5. Number of shallow landslides per $\mathrm{km}^{2}$ in each $Q_{\mathrm{c}}$ category for the combined data set from all 14 study watersheds

We used a non-parametric test for population similarity to evaluate the hypothesis that landslides occur disproportionately in areas of low $Q_{\mathrm{c}}$. The null hypothesis is that the distribution of landslides should occur in direct proportion to the area mapped in each $Q_{\mathrm{c}}$ category if the model does not discriminate relative landslide hazard. Equality of the two populations was tested with Pearson's $\chi^{2}$ statistic for goodness-of-fit for categorized data (Bhattacharyya and Johnson, 1977). The test statistic is computed as

$$
\chi^{2}=\Sigma \frac{(O-E)^{2}}{E}
$$

where $O$ is the observed frequency of landslides in each $Q_{\mathrm{c}}$ category and $E$ is the expected number calculated as the proportion of total landslides based on the area of the watershed in the $Q_{\text {c }}$ category. The test statistic was statistically significant for each watershed (Table III), indicating rejection of the null hypothesis and implying that the model discriminates areas of greater landslide hazard. Hence, $Q_{\mathrm{c}}$ provides a surrogate for failure initiation probability as a function of topographic position, as hypothesized by Montgomery and Dietrich (1994).

Counter to the conventional wisdom that roads cause the vast majority of shallow slides in the Pacific Northwest, the 1881 road-related slides account for just over half $(58 \%)$ of the mapped slides. In most of the watersheds, road-related slides and 'in-unit' slides occur with roughly equal frequency; basins with many road-related slides also have many 'in-unit' slides (Figure 6). However, in two of the watersheds (Chehalis and Vesta/Little North) road-related slides are far more numerous than 'in-unit' slides. Least-squares linear regression of the total number of 'in-unit' slides against the total number of road-related slides for all but these two watersheds yields a relationship of $y=8+0.97 x\left(R^{2}=0.85\right)$, which indicates that road-related and 'in-unit' failure rates account for a comparable number of landslides in the majority of the watersheds. Hence, 'in-unit' failures appear to account for about half the slides on a regional basis, although roads can be responsible for the vast majority of shallow landsliding in particular watersheds. Perhaps even more surprising is that the relationship between $Q_{\mathrm{c}}$ and the relative frequency of road-related failures parallels that for 'in-unit' slides. Road-related slides are concentrated in areas of low $Q_{\mathrm{c}}$; topographic control still seems to dominate the location of road-related slides, which appear to trigger slides in areas prone to failure.

Consistent patterns in watershed sensitivity to reduced root strength can be shown by comparing the predicted extent of potentially unstable ground for low root strength versus that for high root strength. In all of the watersheds, simulations with root strengths of 8 and $16 \mathrm{kN} / \mathrm{m}^{2}$ virtually eliminated areas of potential instability identified in the $2 \mathrm{kN} / \mathrm{m}^{2}$ simulations. For the higher root strength cases, incorporation of a greater soil depth as typically found in topographic hollows, localizes the zones of predicted potential instability in hollows (Dietrich et al., 1995). Hence, a dramatic increase in the rate of shallow landsliding 
Table III. $\chi^{2}$ test statistic for the Pearson goodness-of-fit for categorized data for landslide frequency in $Q_{\mathrm{c}}$ categories modelled at cohesion $=2 \mathrm{kN} / \mathrm{m}^{2}$. Test statistic greater than 18 is significant at $P<0.005$ (at 6 d.f.)

\begin{tabular}{lc}
\hline Watershed & $\chi$ statistic \\
\hline Griffin/Tokul & 311 \\
Tolt & 163 \\
Skookumchuck & 195 \\
Coweeman & 564 \\
Stillman & 420 \\
Chehalis & 1577 \\
Vesta/L. North & 1562 \\
Willapa & 2308 \\
Siuslaw & 249 \\
Millicoma & 382 \\
Mohawk & 132 \\
N. McKenzie & 967 \\
S. McKenzie & 610 \\
\hline
\end{tabular}

should be expected to result from loss of root strength following forest clearance in these steep, soil-mantled basins.

\section{DISCUSSION AND CONCLUSIONS}

The strong correlation between rates of sliding and calculated $Q_{\mathrm{c}}$ indicates that topographic control dominates the location of shallow landslides in Pacific Northwest watersheds. If local geology or site-specific soil or hydrological conditions dominate the distribution of shallow landsliding, then there should be no such pattern and the model should perform poorly. Instead, the model performs surprisingly well given the use of a single set of parameters across a wide range of lithology and topographic settings. Consequently, we interpret our findings as strong support for considering topographically driven convergence of nearsurface runoff as a primary control on shallow landsliding in this region, as has been long-advocated by Dietrich and colleagues (e.g. Dietrich et al., 1982, 1986; Reneau and Dietrich, 1987; Montgomery and Dietrich, 1988).

The importance of topographically driven slide frequency highlights the relationship between shallow landsliding and landscape evolution, as more frequent failure implies more rapid erosion. We interpret our analyses as strong support for the view that shallow landsliding plays a primary role in the incision of headwater valleys in steep terrain, as advocated by Seidl and Dietrich (1992). The inverse exponential form of the relationship between slide frequency and $Q_{\mathrm{c}}$ also provides insight into the construction of a sediment transport law for shallow landsliding. Many landscape evolution models consider sediment flux by landsliding to be a diffusive, slope-dependent process and hence that landslides act to smooth rather than create local relief. In contrast, considering sediment flux by shallow landslides $\left(Q_{\mathrm{s}}\right)$ to depend upon $Q_{\mathrm{c}}$ (i.e. $Q_{\mathrm{s}}=a Q_{\mathrm{c}}^{-b}$ ) would treat landsliding as incisive by including both a slope and an area dependence.

Two types of model error are possible: in type I errors the model predicts that landslides are not likely to occur but they do, whereas in type II errors the model predicts that landslides are likely to occur but they do not. Each watershed has far more area mapped in low $Q_{\mathrm{c}}$ than has actually experienced slope failure. We interpret the model to provide a relative likelihood of failure that can be considered to integrate a stochastic process of failure initiation across time and space. Hence, we consider unfailed areas with low $Q_{\mathrm{c}}$ to delineate likely sites of failure in future storms rather than areas presumed to have been tested and proved stable during previous storms. 


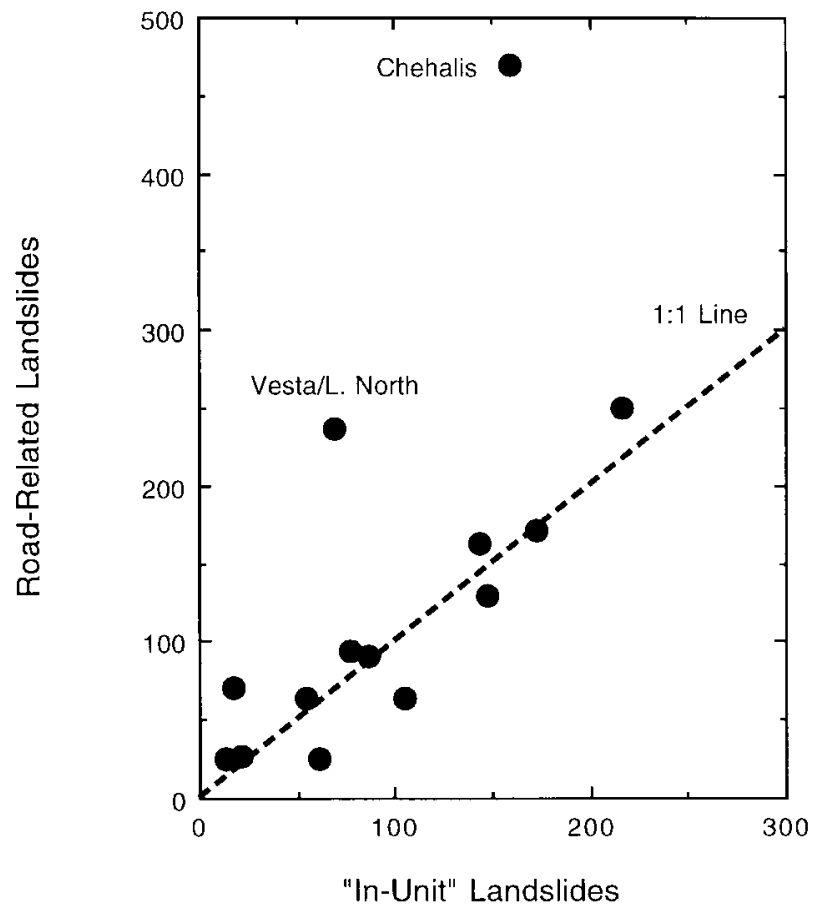

Figure 6. Number of road-related slides versus number of non-road-related slides in each of the study watersheds

A total of $24 \%$ of the mapped landslides occur in areas that the model predicts to be unconditionally stable. Road-related effects account for almost half of these failures and the proportion of such type I errors varied greatly between watersheds. As few as $6 \%$ of the landslides were missed by the model in several watersheds and $88 \%$ of the mapped slides occurred in 'stable' ground in the watershed with the worst model performance (Griffin/Tokul). Many of the type I errors arose from the action of processes external to the model framework and local conditions specific to the study watersheds. The model generally performed well in watersheds underlain by shallow deposits and poorly in areas with thick glacial deposits (e.g. Griffin/ Tokul) where groundwater recharge may control soil saturation and shallow landsliding. Field work in many of the areas where shallow landslides occurred in locations predicted to be unconditionally stable revealed that many of the slides occurred: (i) in steep inner gorges not resolved in the $30 \mathrm{~m} \mathrm{DEMs}$; (ii) from the scarps, flanks and toes of large, deep-seated landslides; and (iii) in association with other local effects such as $30 \mathrm{~m}$ high abandoned logging railroad embankments that do not appear on either $7 \cdot 5^{\prime}$ topographic maps or on $30 \mathrm{~m}$ DEMs (P. Russel, personal communication). Such factors external to the model framework can reasonably account for the $<10 \%$ of the mapped landslides that remain inexplicable within the context of the model.

The influence of roads and lithology on shallow landslide frequency holds several surprising implications. The similar relationship between slide frequency and $Q_{\mathrm{c}}$ for road-related and in-unit slides indicates that the acceleration of landsliding owing to road construction appears to reflect where they are built as much as how they are built. Although the style of road construction can profoundly influence landslide hazards (e.g. Furniss et al., 1991), siting of roads across, or the delivery of road drainage to, potentially unstable ground also has a primary influence on landslide frequency. Our data also confirm that differences in geology impose a broad control on absolute rates of shallow landsliding upon which superimposed topographic controls dominate the relative slide frequency. This suggests the wisdom of dividing large basins or regions into areas of similar geology in order to calibrate modelling of sediment flux or failure rates. Such a larger scale 
geological context is particularly important for interpreting differences in slide frequencies between different watersheds.

The inherent susceptibility of a landscape to changes in $C^{\prime}$ that accompany timber harvest varies dramatically, both within a watershed and regionally. At present, however, relatively little use is made of the differences in landscape susceptibility to timber harvesting in land use planning. Instead, ownership patterns tend to drive definitions of suitable land use independent of the relative risk inherent in the different terrains. Models such as those investigated here could provide useful tools for addressing the inherent capacity of the landscape to sustain particular land uses, a key issue in the design and evaluation of watershed management strategies (e.g. Montgomery et al., 1995).

A key implication of our analyses is that high $C^{\prime}$, as characterizes mature coniferous forest in the Pacific Northwest, effectively limits shallow landsliding to areas with deep soils, such as hollows that fill with colluvium, or where local hydrological conditions lead to excess pore pressures. Processes that lower $C^{\prime}$ (e.g. fire, timber harvesting) should lead to higher probabilities of failure across a greater proportion of the landscape.

Our analysis further motivates discussion of appropriate roles for models in watershed planning. In particular, our data document that $Q_{\mathrm{c}}$ provides a reasonable surrogate for failure probability after timber harvest and that most slides occur from readily identifiable areas in which root strength appears critical to slope stability. Establishing appropriate bounds on what range of $Q_{\mathrm{c}}$ values should be considered hazardous is an important question for use of the model in landslide hazard assessment. One approach is to determine an acceptable level of slide protection (e.g. say to minimize the risk from $80 \%$ of slides) for a watershed and then use the observed landslide record to predict the $Q_{\mathrm{c}}$ value that would impose appropriate protection across the watershed. The appropriate level of protection and the specific land management prescriptions to provide that protection are policy questions that require consideration of risk as well as hazard and a clear set of land use objectives and priorities. Models such as those investigated here can inform development of landslide hazard mitigation measures and provide a theoretical framework for the evaluation and interpretation of both assessment and monitoring of data and the effectiveness of land management prescriptions.

\section{ACKNOWLEDGEMENTS}

This study was supported by the Weyerhaeuser Company, the Cooperative State Research Service, US Department of Agriculture (No. 94-37101-0321), US Forest Service (co-op agreement PNW 93-0441), NSF (grant CMS-9610269) and a gift from the Washington Forest Protection Association. Perianne Russel mapped many of the landslides during watershed analyses and provided insight into interpretation of model performance. Numerous conversations with Bill Dietrich have greatly influenced our thinking on the use and interpretation of the type of model examined here.

\section{REFERENCES}

Benda, L. 1990. 'The influence of debris flows on channels and valley floors of the Oregon Coast Range, USA.', Earth Surf. Process. Landf., 15, 457-466.

Benda, L. and Cundy, T. W. 1990. 'Predicting deposition of debris flows in mountain channels', Can. Geotech. J., 27, $409-417$.

Benda, L. and Dunne, T. 1987. 'Sediment routing by debris flow', in Beschta, R. L., Blinn, T., Grant, G. E., Swanson, F. J., and Ice, G. C. (eds), Erosion and Sedimentation in the Pacific Rim, IAHS Publ., 165, 213-223.

Bhattacharyya, G. K. and Johnson, R. A. 1977. Statistical Concepts and Methods. John Wiley \& Sons, New York, 639 pp.

Brabb, E. E., Pampeyan, E. H., and Bonilla, M. G. 1972. 'Landslide susceptibility in San Mateo County, California, scale 1:62 500', Miscellaneous Field Studies Map, MF-360. US Geological Survey, Washington, D.C.

Brown, G. W. and Krygier, J. T. 1971. 'Clear-cut logging and sediment production in the Oregon Coast Range', Wat. Resour. Res., 7, $1189-1198$

Burroughs, E. R. Jr. 1984. 'Landslide hazard rating for portions of the Oregon Coast Range', in O’Loughlin, C. L., and Pearce, A. J. (eds.), Proceedings of the Symposium on Effects of Forest Land Use on Erosion and Slope Stability, Honolulu, Hawaii, Environment and Policy Institute, University of Hawaii, Honolulu. pp. 265-274. 
Burroughs, E. R. Jr and Thomas, B. R. 1977. 'Declining root strength in Douglas-Fir after felling as a factor in slope stability', Forest Service Research Paper INT-190. US Department of Agriculture, Ogden. 27 pp.

Busoni, E., Sanchis, P. S., Calzolari, C., and Romognoli, A. 1995. 'Mass movement and erosion hazard patterns by multivariate analysis of landscape integrated data: the Upper Orcia River Valley (Siena, Italy) case', Catena, 25, 169-185.

Caine, N. 1980. 'The rainfall intensity-duration control of shallow landslides and debris flows', Geograf. Annal., Ser. A, 62, $23-27$.

Campbell, R. H. 1975. 'Soil slips, debris flows and rainstorms in the Santa Monica Mountains and vicinity, southern California', US Geological Survey Professional Paper 851. US Geological Survey, Washington, D.C. 51 pp.

Carrara, A. 1983. 'Multivariate models for landslide hazard evaluation', Math. Geol., 15, 403-426.

Carrara, A., Pugliese Carratelli, E., and Merenda, L. 1977. 'Computer-based bank and statistical analysis of slope instability phenomena', Z. Geomorph., 21, 187-222.

Carrara, A., Cardinali, M., Detti, R., Guzzetti, F., Pasqui, V., and Reichenback, P. 1991. 'GIS techniques and statistical models in evaluating landslide hazard', Earth Surf. Process. Landf., 16, 427-445.

Derbyshire, E., van Asch, T., Billard, A., and Meng, X. 1995. 'Modelling the erosional susceptibility of landslide catchments in thick loess: Chinese variations on a theme by Jan de Ploey', Catena, 25, 315-331.

Dietrich, W. E. and Dunne, T. 1978. 'Sediment budget for a small catchment in mountainous terrain', Z. Geomorph., 29 (Suppl.), 191-206.

Dietrich, W. E., Dunne, T., Humphrey, N., and Reid, L. 1982. 'Construction of sediment budgets for drainage basins', in Swanson, F. J., Janda, R. J., Dunne, T., and Swanston, D. N. (eds), Sediment Budgets and Routing in Forested Drainage Basins, US Department of Agriculture, Forest Service General Technical Report PNW-141. Pacific Northwest Forest and Range Experiment Station, Portland, Oregon. pp. 2-23.

Dietrich, W. E., Wilson, C. J., and Reneau, S. L. 1986. 'Hollows, colluvium, and landslides in soil-mantled landscapes', in Abrahams, A. D. (ed.), Hillslope Processes. Allen and Unwin, Boston. pp. 361-388.

Dietrich, W. E., Wilson, C. J., Montgomery, D. R., and McKean, J. 1993. 'Analysis of erosion thresholds, channel networks and landscape morphology using a digital terrain model', J. Geol., 101, 259-278.

Dietrich, W. E., Reiss, R., Hsu, M.-L., and Montgomery, D. R. 1995. 'A process-based model for colluvial soil depth and shallow landsliding using digital elevation data', Hydrol. Process., 9, 383-400.

Dunne, T. 1991. 'Stochastic aspects of the relations between climate, hydrology and landform evolution', Trans. Jpn. Geomorph. Union, 12, 1-24.

Endo, T. and Tsuruta, T. 1969. 'The effect of tree roots on the shearing strength of soil', Annual Report. Forest Experiment Station, Hokkaido. pp. 167-182.

Fredriksen, R. L. 1970. 'Erosion and sedimentation following road construction and timber harvest on unstable soils in three small western Oregon watersheds', Forest Service Research Paper PNW-104. US Department of Agriculture. Porland. 15 p.

Furniss, M. J., Roelofs, T. D., and Yee, C. S. 1991. 'Road construction and maintenance', in Meehan, W. R. (ed.), Influences of Forest and Rangeland Management on Salmonid Fishes and Their Habitats. Am. Fish. Soc. Spec. Publ., 19, $297-323$.

Grant, G. E., Crozier, M. J., and Swanson, F. J. 1984. 'An approach to evaluating off-site effects of timber harvest activities on channel morphology', in Proceedings, Symposium on the Effects of Forest and Land Use on Erosion and Slope Stability, Environment and Policy Institute, East-West Center, University of Hawaii, Honolulu. pp. 177-186.

Gresswell, S., Heller, D., and Swanston, D. N. 1979. 'Mass movement response to forest management in the central Oregon Coast Ranges', Forest Service Resources Bulletin PNW-84, US Department of Agriculture, Portland. 26 pp.

Hollingsworth, R. and Kovacs, G. S. 1981. 'Soil slumps and debris flows: prediction and protection', Bull. Assoc. Engng. Geol., 18, $17-28$.

Lanyon, L. E. and Hall, G. F. 1983. 'Land-surface morphology: 2. Predicting potential landscape instability in eastern Ohio', Soil Sci., 136, 382-386.

Mark, R. K. 1992. 'Map of debris-flow probability, San Mateo County, California, scale 1:62 500, Miscellaneous Investigations Map, I-1257-M. US Geological Survey, Washington, D.C.

Martin, K., Skaugset, A., and Pyles, M. R. 1996. 'Forest management of landslide prone sites: the effectiveness of headwall leave areas, part II', COPE Report, 9, 8-12.

Mersereau, R. C. and Dyrness, C. T. 1972. 'Accelerated mass wasting after logging and slash burning in western Oregon', J. Soil Wat. Conserv., 27, 112-114.

Montgomery, D. R. 1991. 'Channel initiation and landscape evolution', PhD Thesis, University of California, Berkeley. 421 pp.

Montgomery, D. R. and Dietrich, W. E. 1988. 'Where do channels begin?', Nature, 336, 232-234.

Montgomery, D. R. and Dietrich, W. E. 1994. 'A physically-based model for the topographic control on shallow landsliding', Wat. Resour. Res., 30, 1153-1171.

Montgomery, D. R., Wright, R. H., and Booth, T. 1991. 'Debris flow hazard migration for colluvium-filled swales', Bull. Assoc. Engng. Geol., 28, 299-319.

Montgomery, D. R., Grant, G. E., and Sullivan, K. 1995. 'Watershed analysis as a framework for implementing ecosystem management', Wat. Resour. Bull., 31, 369-386.

Montgomery, D. R., Dietrich, W. E., Torres, R., Anderson, S. P., Heffner, J. T., and Loague, K. 1997. 'Hydrologic response of a steep unchanneled valley to natural and applied rainfall', Wat. Resour. Res., 33, 91-109.

Neuland, H. 1976. 'A prediction model of landslips', Catena, 3, 215-230.

Neuland, H. 1980. 'Diskriminanzanalytische untersuchungen zur identifikation der auslösefaktoren für rutschungen in verschiedenen höhenstuufen der Kolumbianischen Anden', Catena, 7, 205-221.

Niemann, K. O. and Howes, D. E. 1991. 'Applicability of digital terrain models for slope stability assessment', ITC J., 1991-3, $127-137$.

Okimura, T. and Ichikawa, R. A. 1985. 'Prediction method for surface failures by movements of infiltrated water in a surface soil layer', Natural Disaster Sci., 7, 41-51. 
Okimura, T. and Nakagawa, M. 1988. 'A method for predicting surface mountain slope failure with a digital landform model', Shin Sabo, 41, 48-56.

O'Loughlin, E. M. 1986. 'Prediction of surface saturation zones in natural catchments by topographic analysis', Wat. Resour. Res., 22, 794-804.

Pierson, T. C. 1977. 'Factors controlling debris-flow initiation on forested hillslopes in the Oregon Coast Range', PhD Thesis, University of Washington, Seattle. $166 \mathrm{pp}$.

Reneau, S. L. and Dietrich, W. E. 1987. 'Size and location of colluvial landslides in a steep forested landscape', in Beschta, R. L., Blinn, T., Grant, G. E., Ice, G. G., and Swanson, F. J. (eds), Proceedings of the International Symposium on Erosion and Sedimentation in the Pacific Rim, IAHS Pub., 165, 39-48.

Riestenberg, M. M. and Sovonick-Dunford, S. 1983. 'The role of woody vegetation in stabilizing slopes in the Cincinnati area, Ohio', Geol. Soc. Am. Bull., 94, 506-518.

Seeley, M. W. and West, D. O. 1990. 'Approach to geologic hazard zoning for regional planning, Inyo National Forest, California and Nevada', Bull. Assoc. Eng. Geol., 27, 23-35.

Seidl, M. and Dietrich, W. E. 1992. 'The problem of channel incision into bedrock', in Schmidt, K.-H. and de Poley, J. (eds), Functional Geomorphology, Catena Supplement 23. Catena Verlag, Cremlingen. pp. 101-124.

Selby, M. J. 1982. Hillslope Materials and Processes. Oxford University Press, Oxford. 264 pp.

Sidle, R. C. 1992. 'A theoretical model of the effects of timber harvesting on slope stability', Wat. Resour. Res., 28, $1897-1910$.

Skaugset, A., Froehlich, H., and Lautz, K. 1993. 'The effectiveness of headwall leave areas', COPE Report, 6, 3-6.

Swanson, F. J., and Dyrness, C. T. 1975. 'Impact of clear-cutting and road construction of soil erosion by landslides in the western Cascade Range, Oregon', Geology, 3, 393-396.

Swanson, F. J. Fredriksen, R. L., and McCorison, F. M. 1982. 'Material transfer in a western Oregon forested watershed', in Edmonds, R. L. (ed.), Analysis of Coniferous Forest Ecosystems in the Western United States. Hutchinson Ross Publishing Co., Stroudsburg. pp. 233-266.

Swanston, D. N. and Swanson, F. J. 1976. 'Timber harvesting, mass erosion, and steepland forest geomorphology in the Pacific Northwest', in Coates, D. R. (ed.), Geomorphology and Engineering. Dowden, Hutchinson \& Ross, Inc., Stroudsburg. pp. 199-221.

Takahasi, T. 1968. 'Studies of the forest facilities to prevent landslides', Bull Fac. Agric., Shizuoka Univ., 18, 85-101.

Terwilliger, V. J. and Waldron, L. J. 1991. 'Effects of root reinforcement on soil-slip patterns in the Transverse Ranges of southern California', Geol. Soc. Am. Bull., 103, 775-785.

van Asch, T., Kuipers, B., and van der Zanden, D. J. 1993. 'An information system for large scale quantitative hazard analyses of landslides', Z. Geomorph., 87 (Suppl.), 133-140.

WFPB (Washington Forest Practice Board), 1993. Standard Methodology for Conducting Watershed Analysis, Version 2.0. WFPB, $85 \mathrm{pp}$.

Williams, G. P. and Guy, H. P. 1971. 'Debris avalanches - a geomorphic hazard', in Coates, D. R. (ed.), Environmental Geomorphology. SUNY Publications in Geomorphology, Binghampton. pp. 25-46.

Wu, W. and Sidle, R. C. 1995. 'A distributed slope stability model for steep forested basins', Wat. Resour. Res., 31, 2097-2110.

Wu, T. H., McKinnell, W. P., III, and Swanston, D. N. 1979. 'Strength of tree roots and landslides on Prince of Wales Island, Alaska', Can. Geotech. J., 16, 19-33.

Ziemer, R. R. and Swanston, D. N. 1977. 'Root strength changes after logging in southeast Alaska', Research Note PNW-306. US Forest Service, Pacific Northwest Forest and Range Experiment Station, Portland. 


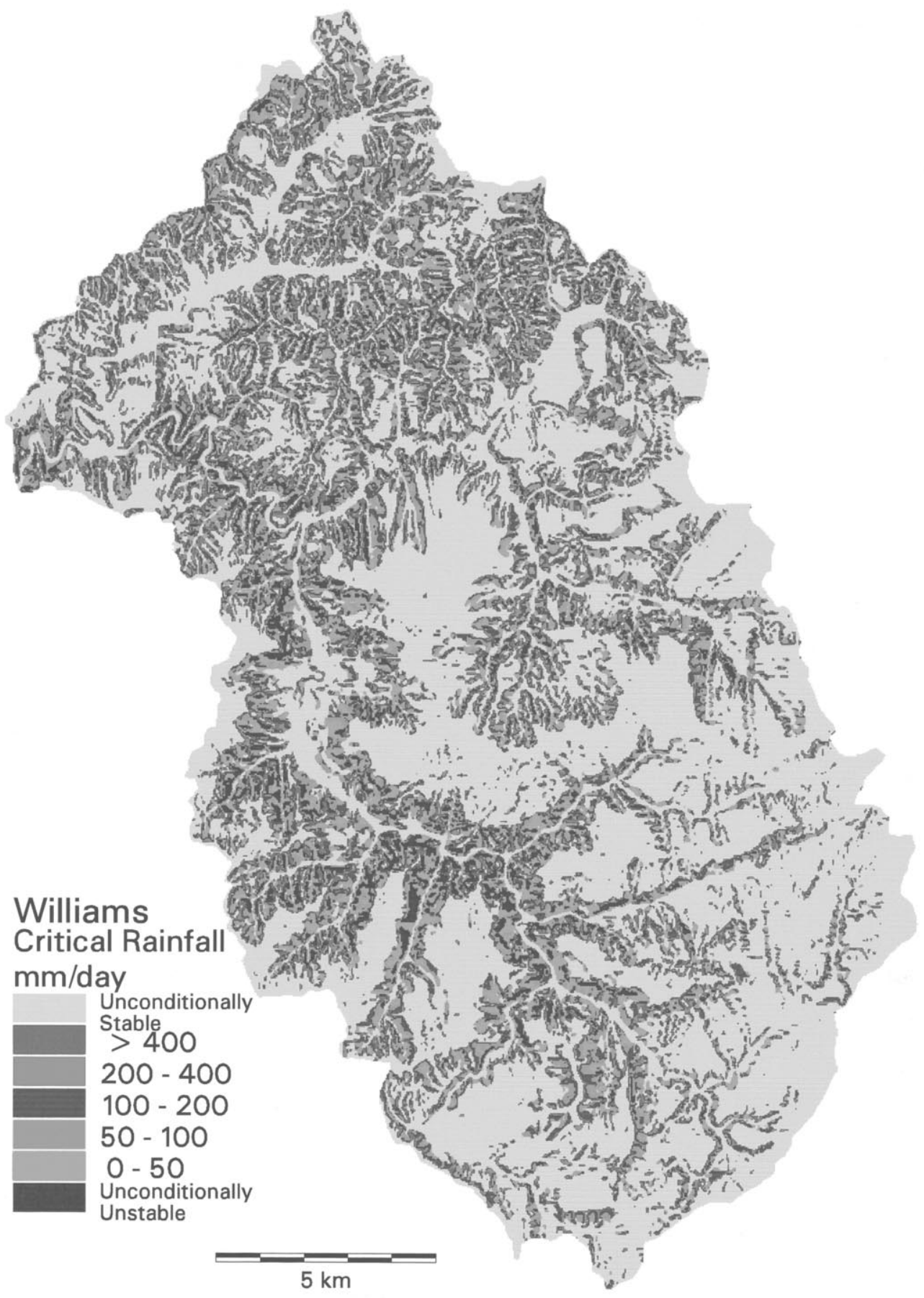

Figure 2(a) 


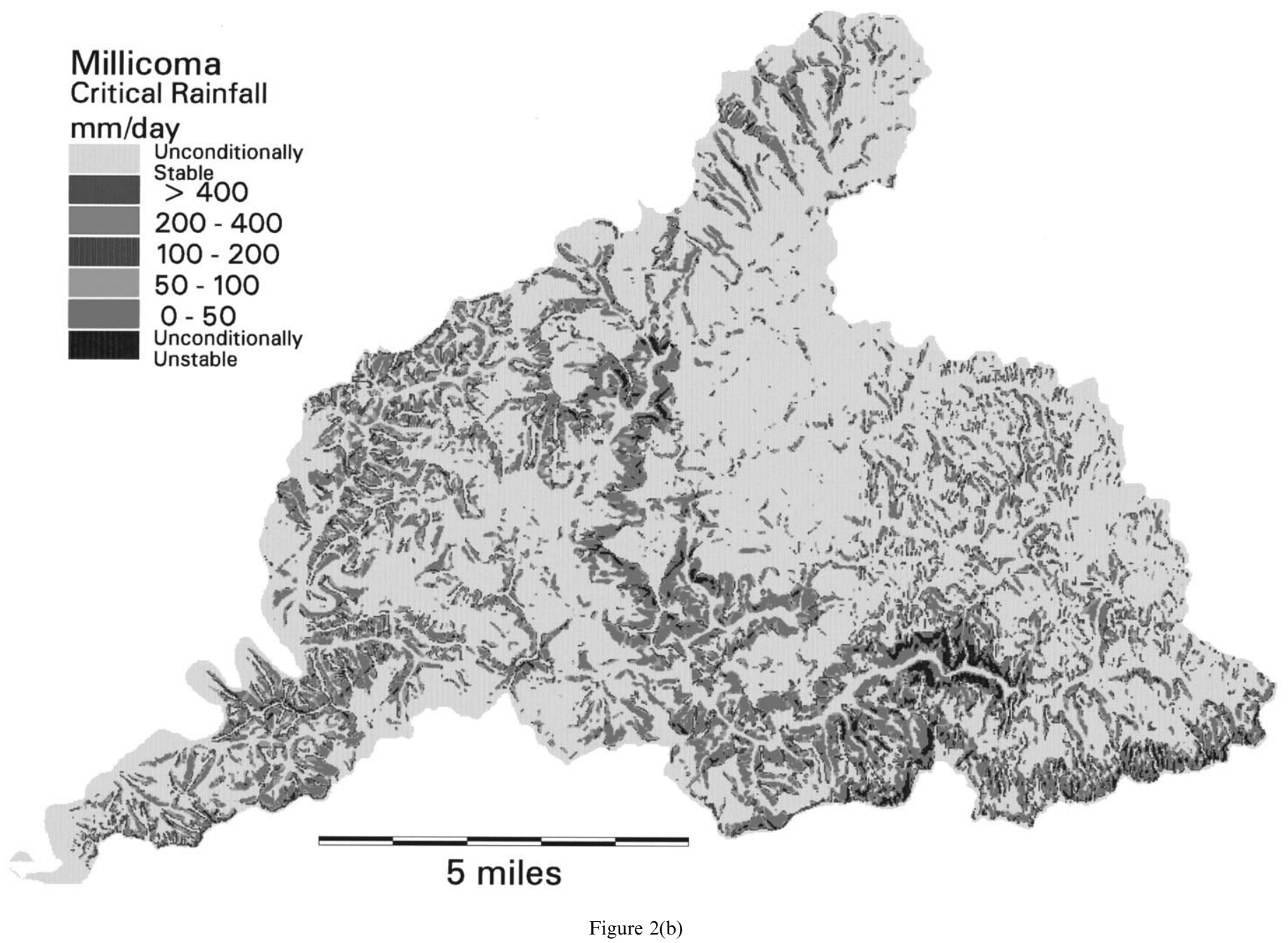

Figure 2(a-b). Maps illustrating the distribution of $Q_{\mathrm{c}}$ values for $C^{\prime}=2 \mathrm{kN} / \mathrm{m}^{2}$ in the Williams and Millicoma watersheds 